\title{
Research on the Computer Ability Training Mode of Professional Talents in Foreign Language Colleges
}

\author{
Kaiyan Sun \\ Jilin Huaqiao University of Foreign Languages, Jilin, Changchun, 130117
}

Keyword: Inter-disciplinary talent; Computer ability; Training mode; Professional disciplines

\begin{abstract}
Through the research on the complex and applied talents training, found that the part of the institutions of higher learning for the cultivation of professional talents is still in the stage of fuzzy. Based on our school as an example, this paper analysis in the fierce market competition, emphasize the necessity of professional compound talent training; From the perspective of theory and practice research of computer ability training mode.
\end{abstract}

\section{Introduction}

The 21st century is an era of information technology, the computer in our country has gained great popularity and application of computer and foreign language ability, also has become one of the basic requirement of unit of choose and employ persons to graduate. However, that some of the popular major in the current job market has appeared the state of oversupply, the cause of this phenomenon are manifold. According to the survey, students according to their own interest to enter oneself for an examination professional accounts for about $40 \%$, less than half, which is engaged in the industry is not satisfied; In addition, the severe employment pressure is also the important cause of profession is not wrong. Talents depend on education, what kind of education to develop to meet the need of 21st century information construction of socialist new people? In the national basic education course reform outline (try out) "pointed out: in the teaching process, to vigorously promote the widely application of information technology, to promote the integration of information technology teaching and discipline curriculum, slowly realize teacher's teaching methods, students learning the way of presenting methods, teaching contents and the reform of the teachers and students interact, play the advantages of information technology, rich powerful learning tool for students and diversified education environment.T herefore, rational planning inter-disciplinary talent, develop computer application ability, high comprehensive quality of foreign language talents more and more get the favour of unit of choose and employ persons in charge of foreign affairs.

\section{The core concept definition of "compound talents"}

Compound talent training is mainly refers to institutions of higher learning in a certain time and education level will have a certain span under the condition of the professional knowledge of penetrating into organic, knowledge structure and ability structure of educatees to optimize combination, become a professional migration ability strong, mastering many skills while specializing in talent education process.Labor personnel department for interdisciplinary talents has the highest current demand fall into three categories: the first is both brain will start work again "gotten" talents, such as education management staff;Followed by both internationalization operation experience and knowledge of the management personnel of local actual situation, such as foreign trade and economic and technical personnel;The third kind is know both technical and marketing talents, such as business planning design personnel and so on.Interdisciplinary talents in our school, however, need to develop a solid language foundation, but also master the modern education technology and other professional skills, make its application to the foreign trade, finance, education, media, science and technology in all walks of life. 
At present, enterprises and positioning of the professional talents of foreign languages institutes is: must have strong English communication skills, broad business operation skills, effective business communication skills, good computer application ability. The course construction of various professional foreign language has formed great challenge.

\section{The defects of professional personnel training mode of local undergraduate colleges and universities}

Most of the college computer basic education has a good foundation, and the corresponding computer public teaching organizations, as well as the relative stability of teacher team. Many colleges and universities of professional compound talent training scheme, however, still there are some realistic problems, lack of education combined with professional computer application demand of the third level of ability, mainly embodied in the following aspects:

1. Part of the local undergraduate colleges and universities of professional teaching still adopt "pass - accept" unified standard mode, to cultivate the students' practical ability enough, not enough advanced teaching methods and teaching means. These are not conducive to the cultivation of students innovation and practical ability.

2. In the case of "Internet +" increasingly development, colleges and universities network information is relatively backward, teachers also need to improve information literacy, information technology teaching and curriculum integration has become the core of the teaching reform.

3. At this stage of computer basis teaching is to cultivate students solid theoretical basis, proficiency in basic operation skills, and the comprehensive quality of the computer. However, computer hardware and software update is slow, computer teaching is hard to combined with market demand.

4. Different professional and professional requirements for the knowledge of computer is distinguishing. Many still exists a single computer foundation course in colleges and universities, the phenomenon of pertinence is not strong.For example: business English, English education professional use of unified teaching materials, such as the syllabus and teaching aim is basically the same.

\section{The strategies of cultivating the computer ability of professional talents}

In order to more quickly adapt to the needs of the development of education, in order to better improve the efficiency of classroom teaching, promote the reform of the education teaching, cultivate students' innovation ability, using computer technology to improve the students' ability of using computer to solve the major professional problem, We combines the actual conditions of different professional discipline teaching characteristic, proposed in the professional teaching to strengthen the research of cultivating the ability of computer, computer courses the close relationship with market needs, develop curriculum system, choose the suitable teaching methods, teaching means and teaching cases, the interdisciplinary professional students' computer application level to a new step, such as production, construction, management, service line service.

The combination of "computer education at the university of four years continuous line course system", continue to practice and improve college students "fundamentals of computer" classification teaching mode reform. In recent semester, we have just entered the university computer ability level test for freshmen, preliminary understanding to the student use of computers. Most students will use computers in the Internet experience, access to information, and so on carry on some simple operation. And the most basic Office software can't use. Therefore, we require a freshman must be required in the course "university computer foundation". In content is mainly to let the students master word processing software, spreadsheets, presentation software such as methods of use of office software; Mainly on the method of using case teaching method combined with the actual office, earnestly practice much; On model mainly adopts tracking collecting students' entrance examination test, test, integrated design, grade exam, final exam "and so on many links, with different stages of the result data analysis student's problem. More emphasis on students 
hands-on capacity-building and to work in the future in efficient, high-quality through everyday office of some of the jobs.

Study professional characteristics, categorizing non-computer professional computer courses, makes more closely with the student's professional computer courses, students in knowledge, ability and thinking in terms of composition. therefore, computer teaching should be according to the different needs of their students learn professional, specialized compulsory course and elective courses. We require a freshman after to master basic computer skills, can take is closely related to this professional computer professional courses. For example, English education professional opened multimedia courseware and the modern education technology; E-commerce professional and hotel management opened a web design and production; Editing professional set up audio and video production and graphic design; Opened a senior excel application in business and administration, and so on. Let the students by taking a professional direction of computer course module to determine their own professional direction. At the same time, also widened the computer teacher's business promotion space, to save funds outside part-time teacher in our school, the shared use of teacher resources.

The following is a nearly five years according to the professional requirements, we increase or decrease in the curriculum:

\begin{tabular}{|l|c||}
\hline \multicolumn{1}{|c|}{ College and professional } & Elective courses \\
\hline \hline Chinese language and literature major & "Modern education technology" \\
\hline \multicolumn{1}{|c|}{ College of English } & "Modern education technology" \\
\hline $\begin{array}{l}\text { Institute of economic and trade professional } \\
\text { e-commerce }\end{array}$ & "The Photoshop graphic design" \\
\hline $\begin{array}{l}\text { Institute of economic and trade professional } \\
\text { e-commerce }\end{array}$ & "E-commerce web design" \\
\hline $\begin{array}{l}\text { Institute of economic and trade professional } \\
\text { e-commerce }\end{array}$ & "Video frequency Processing" \\
\hline $\begin{array}{l}\text { Institute of economic and trade professional } \\
\text { e-commerce }\end{array}$ & "SQL database" \\
\hline $\begin{array}{l}\text { Industrial and commercial management institute } \\
\text { majoring in tourism management }\end{array}$ & "E-commerce web design" \\
\hline $\begin{array}{l}\text { Industrial and commercial management institute } \\
\text { majoring in tourism management }\end{array}$ & "Graphic design" \\
\hline Institute of han Chinese language major & "The Photoshop graphic design" \\
\hline Han institute majoring in editing and publication & "Web design" \\
\hline $\begin{array}{l}\text { English Language Institute of British media } \\
\text { professional }\end{array}$ & "Web design" \\
\hline $\begin{array}{l}\text { College of liberal arts education major } \\
\text { The whole institute public Selected Courses } \\
\text { (Based on the students' interest in to create } \\
\text { courses) }\end{array}$ & "Multimedia Courseware Manufacture" \\
\cline { 2 - 3 } & "Access Database" \\
\cline { 2 - 3 } & "Audio and video editing and production" \\
\hline
\end{tabular}

Community is an important part of campus culture construction, is the student presentation skills of the platform. Therefore, we should build more diversification, specialization, specialty, practice community. At the same time, as the extension of teaching content, we should set up for students bridge "college computer design competition", stimulate students' interests and potential, training 
students' practical ability to solve practical problems by employing information technologies, enhance team collaboration and innovation consciousness of college students, and the discipline competition work into practice for the construction of the teaching reform.We can use the platform to let the students to learn computer knowledge fully practice drills, improve their professional skills, promote students to excavate potential, develop the students' personality development.

Computer development faster and faster, with the old version software upgrade, the new software. In order to keep up with the demands of the development of modern technology, our teacher will be added in a timely manner and continuous updating the teaching contents, setting up the teaching content should be targeted, the most important thing is that should be closely integrated and practical application; At the same time, with practical and advanced practice content as the main line, according to the teaching outline, teaching material writing case, and update the teaching material, teaching content must be original, and the school of software and hardware configuration, so that students learn up is thought to be more practical.

A computer is a practical subject, it is not enough to rely on class time, we will extends to the extracurricular teaching activities, the modern education technology as support mode, open learning environment for students, the autonomous learning content and requirements of computer technology into the teaching plan. Therefore, the teachers teaching through daily accumulation, sorting and constantly enrich the existing teaching resource and putted forward, at the same time to promote the use of network teaching platform to all students, making it become the students self-study, widen our sight and mentoring effective means of answering questions. In addition, for each course we increase the integrated design, simulate the business process, the professional knowledge and skills they learned in class in class under the comprehensive application, to improve students' creativity and problem solving skills; At the same time, will also be the teacher's transformation from the traditional single impart knowledge as the main function of inspired motivate students independent thinking, to cultivate the students to develop good study habits.

6. Promote exchanges and cooperation, interactive functions into full play

Organize regular teachers teaching exchange, teacher training plan, promote the teachers to learn; And through meetings and take an active part in the province (state) computer teaching activities, deep research into enterprises and carry out special investigation, and his brother universities exchanges of visits, understand the industry forefront theory, to provide diversified development platform for teachers, improve their comprehensive quality, to further explore the application effect of professional disciplines and the integration of computer courses, which complement each other.

\section{Professional student computer capacity-building focus and innovative point}

We are based on the problems, based on practice, based on the research of application, the focus is on the computer and other subjects have merged, find a new one; Then around after graduation are engaged in work related professional to carry out the practice teaching link, pay attention to cultivate student's ability to obtain knowledge, make the students master updated cutting-edge computer knowledge, the initiative development. However, professional disciplines and computer courses to fusion, not overnight work. Information age fast development, caused the we formulate perfect curriculum system structure and specialized subject may not be synchronized. A school curriculum system structure is not easy, once developed, also want to go through several semesters, and even a few years of practice, according to the requirements of professional courses in new computer can't be achieve in a short period of time.

Therefore, we are going to the computer science and professional talent training target is applied, the foreign language college training mode of "professional + computer ability", embodied in "software application as the core, the practical ability as the center of gravity", to strengthen professional practice training course, according to the professional requirements, points module to open the computer course.

The cultivation of professionals in computer power to keep up with the development of technology trends. In view of the objective and professional characteristics, we in practice to systematically study the ways and methods of cultivating and laws, and in the course design of the 
large number of professional and specialized data included, first to ensure the advancement of teaching; Second, we reduce the theory class hours of the teaching content, increase technology course, practice course and the comprehensive design course on the number of classes, meet students professional teaching skills, solve the problem of poor students' practical ability, realize the integration of practice and theory innovation; Third, we have broken the traditional teaching structure, take the initiative to adjust the training objective and curriculum setting, personnel training mode of tool that slam the door in the past, to cultivate innovative quality and social responsibility, fully embodies the culture of foreign language colleges and characteristics of composite discipline structure; Fourth, in order to research the leading driving research work, the implementation of diversified teaching mode, namely the innovative teaching methods and teaching structure, more attention to the training process of students and to our teachers' personal development also provides a development platform, finally realizes the resource sharing.

\section{Conclusion}

The practice proved that ability to cultivate professional talents for computer work is a difficult task, we need to continue to explore research and innovation. To cultivate students a solid academic background and interdisciplinary talents of computer application, enhance the students' social adaptability, there must be a batch of dare to bear hardships, dedicated people's teacher, and relying on the advantage of multimedia and network teaching, pay attention to the students' professional knowledge and computer courses together, make sure that the inheritance and development of students' professional characteristics. Though our research from two aspects of theoretical exploration and practice research, makes every effort to the overall effect, but there are still quite a lot of experience. Exploring instructional design in the use of information technology in how to accomplish artful, careful, precise, how to make advanced computer technology to better service for professional construction besides, how to reflect more wide marketability, according to their aptitude, focus on students' personalized development, how to reflect the diversity of its professional ability, these are we must face the problem of thinking and in the future.Therefore, we has yet to be further in-depth study, to adapt the demand of social development.

\section{Acknowledgment}

This paper is a periodic result of Jilin Provincial Association of Higher Education---" Research on the computer ability training of the professional compound talents in foreign language colleges".

(JGJX2017D221)

\section{Reference}

[1]Dong Hongqing. Vocational Colleges The Talent Training Scheme [J]. Journal Of Vocational And Technical Education In China, 2010

[2]Sue R.Crull. Computer Assisted Teaching [J].American Sociological Association,2017

[3]Sun Kaiyan. Based On The Discipline And The Computer Curriculum Integration Design Research [J]. Journal Of Economic Management, 2015

[4]Deng Xiaoni, Chen Yongzhong, Tan Jie Ling. Foreign Language Specialized Undergraduate Student Computer Capacity Raise Idea And Mentality[J]. Higher Education Research Journal, 2003 